\title{
MANAJEMEN BUDAYA KEISLAMAN DI SDIT AL FIRDAUS
}

\author{
Management of Islamic Culture at SDIT AI Firdaus
}

\section{Inuriya Verawati ${ }^{1 *}$}

\section{Ihsan Ramadhani}

* 'Universitas Achmad Yani, Banjarmasin, Kalimantan Selatan, Indonesia

2 Universitas Achmad Yani, Banjarmasin, Kalimantan Selatan, Indonesia

*email:

inuriyarachman@uay.ac.id

\begin{abstract}
Abstrak
Penelitian ini bertujuan untuk mengetahui: I) bagaimana cara SDIT AI Firdaus menerapkan manajemen budaya keislaman di sekolah, dan 2) memberikan gambaran yang detail tentang beberapa faktor yang mendukung dan menghambat dalam penerapan budaya keislaman di SDIT AI Firdaus. Penelitian ini merupakan penelitian kualitatif lapangan dengan teknik pengumpulan data yaitu: observasi, wawancara, dan dokumentasi. Analisis data dalam penelitian ini berupa teknik analisis deskriptif, yaitu metode analisis data yang berupa kata-kata, gambar dan bukan angka. Hasil penelitian ini meliputi: I) Manajemen budaya keislaman di SDIT AI Firdaus dapat dikategorikan baik, dengan dilaksanakannya kegiatan yang sesuai dengan dokumen pengelolaan, pengarahan, monitoring, pemberdayaan, motivating, dan adanya evaluasi. 2) Adapun faktor pendukung dan penghambat penerapan manajemen budaya keislaman di SDIT AI Firdaus meliputi : Faktor pendukung, komitmen dari top manajemen, dukungan warga sekolah, dan fasilitas pembelajaran yang representatif. Faktor penghambat, Orang tua siswa belum terbiasa dengan budaya keislaman, dan belum optimalnya penerapan sanksi, dalam perwujudan budaya keislaman di SDIT AI Firdaus.
\end{abstract}

\section{Kata Kunci: \\ Manajemen \\ Budaya \\ Islam \\ Keywords: \\ Management \\ Culture \\ Islam}

\section{Accepted}

September 2020

Published

December 2020

\begin{abstract}
This study aims to determine: I) how does SDIT Al Firdaus implement Islamic culture management in schools, and 2) provides a detailed description of several factors that support and hinder the application of Islamic culture at SDIT Al Firdaus. This research is a qualitative field research with data collection techniques, namely: observation, interviews, and documentation. Data analysis in this research is in the form of descriptive analysis technique, namely the method of analyzing data in the form of words, pictures and not numbers. The results of this study include: I) Managementlslamic culture in SDIT AI Firdauscan be categorized as good, with the implementation of activities in accordance with management documents, direction, monitoring, empowerment, motivating, and evaluation. 2) The factors supporting and inhibiting the application of cultural managementlslamic in SDIT Al Firdausinclude: Supporting factors, commitment from top management, support from school residents, and representative learning facilities. Inhibiting factors, parents of students are not familiar with Islamic culture, and the application of sanctions has not been optimal, in the embodiment of Islamic culture in SDIT Al Firdaus.
\end{abstract}

(C) 2020 The Authors. Published by Institute for Research and Community Services Universitas Muhammadiyah Palangkaraya. This is Open Access article under the CC-BY-SA License (http://creativecommons.org/licenses/by-sa/4.0/).

\section{PENDAHULUAN}

Kemajuan suatu bangsa dapat dilihat dari seberapa maju pendidikan yang telah dicapai. Pendidikan merupakan faktor penentu dalam menciptakan kemajuan bangsa. Pendidikan juga mendukung tercapainya pembangunan nasional. Untuk dapat mewujudkan pembangunan nasional melalui pendidikan, perlu pemberdayaan manusia yang berkualitas. Peningkatan kualitas sumber daya manusia merupakan syarat mutlak untuk mencapai tujuan pembangunan.

Salah satu cara untuk meningkatkan kualitas sumber daya manusia tersebut adalah melalui pendidikan. Kualitas satuan pendidikan sangat ditentukan oleh manajemen sekolah tersebut. Tujuan 
utama pendidikan adalah untuk meningkatkan sumber daya manusia baik dari perbaikan karakter maupun peningkatan keterampilan yang dimiliki. Agar mutu pendidikan meningkat, perlu dilakukan beberapa upaya secara konvensional maupun inkonvensional. Konsep manajemen budaya sekolah penting untuk diterapkan di sebuah lembaga pendidikan. Peningkatan kualitas pendidikan merupakan suatu proses yang terintegrasi dengan proses peningkatan kualitas sumber daya manusia itu sendiri. Menyadari pentingnya proses peningkatan kualitas sumber daya manusia, pemerintah bersama kalangan swasta terus berupaya mewujudkan amanat tersebut melalui berbagai usaha pembangunan pendidikan yang lebih berkualitas, tetapi pada kenyataannya upaya pemerintah tersebut belum cukup dalam meningkatkan kualitas pendidikan Indonesia.

Agar mutu meningkat, selain dilakukan secara konvensional perlu diiringi pula dengan pendekatan inkonvensional. Berdasarkan pengalaman tersebut, maka beberapa peneliti dalam bidang pendidikan memberikan arah baru, bahwa budaya unit - unit pelaksana kegiatan yang ada di sekolah turut menjadi salah satu faktor penentu dalam meningkatkan mutu pendidikan. Konsep dari manajemen budaya sekolah secara khusus penting dalam pendidikan, karena bertolak dari sebuah konsep organisasi yang baik dengan kepemimpinan yang baik, harus diikat pula oleh nilai-nilai yang diyakini oleh manajer dan bawahannya, sehingga diperlukan proses yang panjang untuk menumbuhkannya, dimana peran manajemen dalam budaya sekolah dibentuk dan dikembangkan tidak lain dengan berbagai proses manajemen.

Masaong (2011:150) menyatakan budaya sekolah diartikan sebagai sistem makna yang dianut oleh warga sekolah yang membedakannya dengan sekolah lain. Budaya sekolah dapat dideskripsikan sebagai karakteristik khas sekolah yang dapat diidentifikasi melalui nilai yang dianutnya, sikap yang dimilikinya, kebiasaan-kebiasaan yang ditampilkannya, dan tindakan yang ditunjukkan oleh seluruh personel sekolah sehingga membentuk satu kesatuan khusus dari sistem sekolah. Selanjutnya Arifin (2019:2) menerangkan bahwa budaya sekolah memiliki pengaruh positif dalam proses belajar dari seleuruh stakeholders pendidikan. Oleh karena itu, nilai- nilai positif dari budaya sekolah haruslah dibangun oleh pikiran-pikiran manusia. Pikiran manusia tersebut kemudian menghasilkan apa yang disebut dengan "pikiran organisasi”. Dari pikiran organisasi itulah kemudian muncul dalam bentuk nilai-nilai yang diyakini bersama, dan kemudian nilai-nilai tersebut akan menjadi bahan utama pembentukan budaya sekolah, sehingga dari budaya tersebut kemudian muncul dalam berbagai simbol dan tindakan yang kasat indra yang dapat diamati dan dirasakan dalam kehidupan sekolah seharihari.

Pada latar sekolah Islam, norma - norma agama senantiasa dijadikan sumber pegangan yang melandasi perilaku, tradisi, kebiasaan, keseharian, dan simbolsimbol yang dipraktikkan oleh seluruh warga sekolah. Pola pembiasaan dalam sebuah budaya sebagai sebuah nilai yang diakuinya bisa membentuk sebuah pola prilaku. Ketika suatu praktek sudah terbiasa dilakukan, berkat pembiasaan ini maka akan menjadi habit bagi yang melakukannya, kemudian pada waktunya akan menjadi tradisi yang sulit untuk ditinggalkan. Hal seperti ini berlaku untuk hampir semua hal, meliputi nilai-nilai yang buruk maupun yang baik. Konsekuensi dari pembiasaan tersebut adalah bahwa sekolah harus mewujudkan praktik pembiasaan, baik untuk hal-hal yang berkaitan dengan nilai-nilai agama maupun nilainilai sosial. Oleh karena itu, para peneliti pendidikan lebih memfokuskan pada kultur sekolah, bukannya kultur masyarakat secara umum sebagai salah satu faktor penentu kualitas sekolah.

Berbagai perkembangan dan kemajuan ilmu pengetahuan serta teknologi, seperti kemajuan teknologi komunikasi, informasi dan unsur budaya lainnya akan mudah diketahui masyarakat. Kecenderungan seperti itu harus diantisipasi oleh dunia 
pendidikan (Islam) jika ingin menempatkan peran agama pada visi sebagai agen pembangunan yang tidak ketinggalan zaman.

Daradjat (2009:69) menyatakan bahwa sebagai orang tua yang bertanggung jawab terhadap perkembangan anaknya, maka hal ini menjadikan orang tua lebih selektif terhadap apa saja yang dikonsumsi anak, baik bacaan, tontonan dan sebagainya. Salah satunya adalah orang tua menjadi selektif memilihkan sekolah yang tepat bagi anak-anaknya. Perkembangan agama pada anak sangat ditentukan oleh pendidikan dan pengalaman yang dilaluinya, terutama pada masamasa pertumbuhan yang pertama (masa anak) dari umur 0-12 tahun. Seorang anak yang pada masa anak itu tidak mendapat didikan agama dan tidak pula mempunyai pengalaman keagamaan, maka ia nanti setelah dewasa akan cenderung kepada sikap negatif terhadap agama.

Hadiawati (2008:18) menjelaskan bahwa pembentukan anak yang utama yaitu pada masa anakanak. Jika anak dibiarkan melakukan sesuatu pekerjaan yang kurang baik kemudian telah menjadi kebiasaannya, maka akan sukarlah meluruskannya. Artinya pembinaan agama itu wajib dimulai sejak masa anak-anak, jangan sampai anak dibiarkan tanpa pendidikan, bimbingan, pembinaan dan petunjuk agama yang benar. Saat ini yang sedang marak adalah, kecendrungan orangtua memilih sekolah - sekolah yang berlabel "Islam", karena mereka berharap banyak bahwa di sekolahsekolah yang berlabel "Islam", anak-anaknya tidak hanya mengetahui dan mahir dalam pengetahuan dan keilmuan, tetapi anak-anaknya juga akan mengenal tentang Tuhannya, agamanya, dan aturan-aturan dalam beragama. Di sinilah tantangan sekaligus peluang bagi pengelola lembaga pendidikan Islam untuk mampu merealisasikan harapan orangtua dan masyarakat. Untuk mampu merealisasikan harapan orangtua dan masyarakat tersebut, tentunya setiap lembaga harus memiliki strategi untuk meningkatkan kualitas pendidikannya, karena itu, budaya sekolah diharapkan menjadi ujung tombak keberhasilan lembaga dalam mengadakan proses-proses pendidikan untuk mencapai tujuan bersama dalam dunia pendidikan Islam yaitu muslim yang ber-IPTEK dan ber-IMTAK.

Mewujudkan hal tersebut Sekolah Dasar Islam Terpadu Al Firdaus yang berdiri pada tahun 2014 oleh Yayasan Bina Insan Madani dengan tujuan SDIT AI Firdaus bukan sekedar menguasai perkembangan IPTEK semata, tetapi menjadikan pribadi yang beriman, bertakwa, berkarakter, santun serta berguna bagi kehidupan berbangsa dan bernegara, sehingga diperlukan suatu bentuk pengelolaan budaya sekolah islami sesuai tuntunan ajaran islam, atau yang dikenal dengan manajemen budaya keislaman. Manajemen budaya keislaman di SDIT Al Firdaus didasari dengan strategi atau pendekatan dalam penerapan budaya islami sesuai dengan pembentukan karakter siswa sekolah dasar serta sesuai perkembangan zaman.

Berdasarkan latar belakang tersebut, maka peneliti melakukan penelitian di SDIT Al Firdaus dengan maksud dan tujuan untuk mengetahui : I) bagaimana cara SDIT Al Firdaus menerapkan manajemen budaya keislaman di sekolah dan 2) memberikan gambaran yang detail tentang beberapa faktor yang mendukung dan menghambat dalam penerapan budaya keislaman di sekolah.

\section{METODOLOGI}

Pendekatan yang akan digunakan pada penelitian ini menggunakan pendekatan kualitatif dan dideskripsikan secara dedukasi yang berangkat dari teori-teori umum, lalu dengan observasi untuk menguji kebenaran teori tersebut untuk kesimpulan. Kemudian dijabarkan secara deskriptif. Sedangkan jenis penelitiannya berdasarkan tempat adalah penelitian lapangan (field research) dan studi pustaka. Studi pustaka digunakan untuk melakukan pengumpulan data dari berbagai literatur yang berkaitan dengan masalah yang dibahas. Penelitian lapangan (field research) digunakan pengumpulan data dari objek penelitian, dan 
berupa data kualitatif, serta jenis penelitian berdasarkan tekniknya adalah survey research HASIL PENELITIAN DAN (Penelitian Survey), karna tidak melakukan perubahan (tidak ada perlakuan khusus) terhadap variabel yang diteliti. Dengan metode kualitatif, peneliti diharapkan dapat menggali data-data tentang penerapan manajemen budaya keislaman dan faktor yang mendukung serta faktor penghambat manajemen budaya keislaman di SDIT Al Firdaus, yang kemudian akan dianalisis dan dikaji untuk mendeskripsikan hasil temuan dalam bentuk tulisan.

Metode pengumpulan data yang digunakan peneliti di SDIT AI Firdaus terbagi menjadi dua, yaitu data primer dan data sekunder. Data primer, yaitu sumber data yang diperoleh secara langsung melalui observasi dan interview. Data primer peneliti gunakan untuk mengamati secara langsung pelaksanaan manajemen budaya sekolah islami di SDIT AI Firdaus. Sedangkan interview atau wawancara dilaksanakan secara lisan dalam pertemuan daring dan googleform. Metode ini digunakan untuk mendapatkan data tentang bagaimana pelaksanaan manajemen budaya sekolah islami. Pedoman wawancara yang peneliti gunakan adalah wawancara tidak terstruktur, yaitu pedoman wawancara yang hanya memuat garis besar yang akan ditanyakan. Wawancara ini juga digunakan sebagai media crosscheck peneliti dalam menginterpretasikan data yang kurang dapat ditangkap maksudnya dan untuk memperoleh kejelasan dari proses observasi yang bersifat mendukung data penelitian. Data sekunder, yaitu sumber data yang mendukung dan melengkapi sumber data primer berupa dokumentasi. Data sekunder peneliti gunakan untuk mendapatkan dokumen - dokumen yang berkaitan dengan manajemen budaya keislaman di SDIT AI Firdaus dalam melengkapi analisis data primer. Data sekunder dalam penelitian ini berupa visi, misi, tujuan SDIT Al Firdaus dalam penerapan manajemen budaya keislaman, faktor pendukung dan faktor penghambat manajemen budaya keislaman di SDIT AI Firdaus. 
I) Komitmen dari Top management

Pola hubungan atau komunikasi yang diterapkan dengan pendekatan pada masing masing unit kerja di seluruh lingkungan manajemen Yayasan Insan Madani hingga masing - masing unit pendidikan (kepala sekolah dan anggota, membuahkan kedekatan personal antara yayasan dengan pimpinan di semua unit pendidikan di SDIT Al Firdaus.

2) Dukungan warga sekolah

Komitmen serta loyalitas yang penuh dari warga sekolah dalam rangka menerapkan budaya keislaman di SDIT Al Fidaus berimplikasi positif bagi mutu pendidikan baik internal maupun eksternal.

3) Fasilitas pembelajaran yang representatif

Fasilitas dan sarana merupakan alat langsung yang digunakan dalam sebuah lembaga pendidikan untuk mencapai tujuan pendidikan. Diterapkannya sistem reward and punishment

4) Penerapan reward and punishment bagi siswa, guru dan karyawan, seperti adanya nilai tambahan untuk kenaikan pangkat dan juga sanksi penundaan kenaikan pangkat bagi yang sering melanggar.

\section{Analisis Faktor Penghambat Penerapan Manajemen Budaya Keislaman di SDIT Al Firdaus}

Adapun faktor penghambat penerapan manajemen budaya keislaman di SDIT Al Firdaus diantaranya :

I) Orang tua siswa belum terbiasa dengan budaya keislaman, seperti merokok di area sekolah, dan busana wali siswa yang belum memenuhi adab busana islami ketika memasuki sekolah

2) Belum optimalnya penerapan sanksi sebagai perwujudan budaya keislaman di sekolah.

Berdasarkan analisis penerapan, faktor pendukung, dan faktor penghambat penerapan budaya keislaman di SDIT AI Firdaus, jika melihat kompleksitas karakteristik yang dijadikakan indikator keberhasilan pelaksanaan manajemen budaya keislaman di sebuah sekolah, maka manajemen budaya keislaman di SDIT Al Firdaus dapat dikategorikan baik, karena sudah menerapkan perencanaan, pengelolaan, pengarahan, monitoring, pemberdayaa, motivating, dan adanya evaluasi.

\section{KESIMPULAN DAN SARAN KESIMPULAN}

Berdasarkan penelitian dan pembahasan tentang manajemen budaya kei slaman di SDIT Al Firdaus, disimpulkan bahwa :

I. Manajemen budaya di SDIT Al Firdaus dikatakan baik dikarenakan dilaksanakannya kegiatan yang sesuai dengan dokumen pengelolaan, pengarahan, monitoring, pemberdayaan, motivating, dan adanya evaluasi. Disamping itu pula dari yayasan, kepala sekolah, guru, tenaga tata usaha, dan siswa telah membuat pola komunikasi yang dinamis, harmonis, meningkatnya prestasi akademik, dan terciptanya lingkungan sekolah kondusif.

2. Adapun faktor pendukung dan penghambat penerapan manajemen budaya keislaman di SDIT AI Firdaus, meliputi :

a. Faktor Pendukung

I) Komitmen dari top manajemen,

2) Dukungan warga sekolah, dan

3) Fasilitas pembelajaran yang representatif.

b. Faktor Penghambat

I) Orang tua siswa belum terbiasa dengan budaya keislaman, dan

2) Belum optimalnya penerapan sanksi, dalam perwujudan budaya keislaman di SDIT AI Firdaus

\section{SARAN}

I. Bagi Pihak Sekolah

a. Mempertahankan nilai - nilai Islami yang sudah diterapkan kedalam budaya sekolah islami agar 
mewujudkan sekolah yang semakin maju dan berkembang.

b. Meningkatkan dan membimbing serta mendidik siswa dalam melaksanakan budaya islami agar dapat membentuk karakter siswa menjadi saleh dan sholehah.

2. Bagi Orang tua

Perlu meningkatkan pengawasan kepada anaknya saat di rumah agar penanaman nilai - nilai budaya islami dapat berjalan dengan baik.

3. Bagi Peneliti lainnya

Dapat mengembangkan penelitian serupa dengan lingkup variabel yang luas dan berbeda

\section{REFERENSI}

Arifin. 2019. Penumbuhan Budi Pekerti Melalui Penguatan Budaya Sekolah Di SMA Negeri 5 Kupang. Jurnal Ilmiah. Vol 6 No I ; I-I3.

Daradjat, Zakiah 2009. Ilmu Jiwa Agama. Jakarta: Bulan Bintang, cet. 17.

Hadiawati, Lina. 2008. Pembinaan Keagamaan Sebagai Upaya Meningkatkan Kesadaran Siswa Melaksanakan Ibadah Shalat. Jurnal Pendidikan Universitas Garut. Vol. 02, No. I ; 18.

Masaong, A. K \& Ansar. 20II. Manajemen Berbasis Sekolah (Teori, Model dan Implementasi. Gorontalo:Senta Media.

Wahab, A.A . 2008. Anatomi Organisasi Pendidikan \& Kepemimpinan Pendidikan Telaah Terhadap Organisasi \& Pengelolaan Organisasi Pendidikan. Bandung:Alfabet 